\title{
Ortopedi ve Travmatolojide ön inceleme ve muhakkik (ön incelemeci) değerlendirmesi
}

\section{Preliminary review and preliminary reviewer assessment in Orthopedics and Traumatology}

\author{
İrfan Esenkaya* \\ Ortopedi ve Travmatoloji Uzmanı, Emekli Öğretim Üyesi
}

\begin{abstract}
4483, 657 ve 2547 sayılı Kanunların ilgili maddelerine göre soruşturma yapılırken ön inceleme aşamasında muhakkik (ön incelemeci) görevlendirilir. Ayrıca, farkIı kurumlar kendi bünyelerinde disiplin soruşturmaları yaparken ön incelemeci görevlendirir. Bazı kurumlar da kendilerine özgü iş akış süreçleri oluşturur. Yazının birinci bölümünde; 4483 sayılı Kanuna göre memurlar ve diğer kamu görevlilerinin görevleri sebebiyle işledikleri suçlardan dolayı yargılanabilmeleri için izin vermeye yetkili mercilerin (makamların) belirlenmesi ve izlenecek usul (yol) ile ilgili Kanun maddeleri değerlendirildi. Daha sonra, İstanbul il Sağlık Müdürlüğü Disiplin Şube Müdürlüğünce yayımlanan iş akış süreci gözden geçirildi. Yazının ikinci bölümünde; 657 ve 2547 sayılı Kanunların ve diğer yönetmeliklerin disiplinle ilgili bölümlerindeki ilgili maddeler değerlendirildi. SABIM ve CIMER kanallarıyla veya değişik kurumlar aracılığı ile il Sağlık Müdürlüğüne gelen ihbar ve şikâyetlerin değerlendirilmesinin nasıl yapıldığı gözden geçirildi. Daha sonra konuyla ilgili olarak İstanbul il Sağlık Müdürlüğü Disiplin Şube Müdürlüğünce yayımlanan iş akış süreci gözden geçirildi.
\end{abstract}

Anahtar sözcülkler: ortopedi ve travmatoloji; ön inceleme; ön incelemeci
When conducting an investigation in accordance with the relevant clauses of the Laws 4483, 657, and 2547, the institution appoints a preliminary reviewer (examiner) at the initial stage. In addition, different institutions appoint preliminary examiners while conducting disciplinary investigations within their organizations, and some institutions create their own workflow processes. In the first section of this article; we evaluated the provisions of the Law 4483 on the determination of the authorities authorized to give trial permission for the crimes committed by civil servants and other public officials due to their duties, and the procedure to be followed. Then, the workflow process published by the Istanbul Provincial Health Directorate Discipline Department was reviewed. In the second part of the article; the relevant clauses in the disciplinary sections of Laws 657 and 2547, and other regulations (by-laws) were evaluated, and we reviewed how the complaints and notices received through SABIM and CIMER channels or various institutions are examined by the Provincial Health Directorate. Then, the workflow process published by the Istanbul Provincial Health Directorate Discipline Department was analyzed.

Key words: orthopedics and traumatology; preliminary review; preliminary reviewer

nedenle, farklı kurumlar kendi bünyelerinde disiplin soruşturmaları yaparken kendi iş akış süreçlerini oluşturur. ${ }^{[6,7]}$

Her ne kadar konumuz ön inceleme ve muhakkik (ön incelemeci) değerlendirmesi ise de, çalıştığımız kurumlar ve konumumuz gereği ön incelemeci olarak görevlendirilebildiğimiz gibi, bazen şikâyet edilen de olabiliriz. Türk Ceza Kanunu, Madde 4'e göre, "Ceza kanunlarını bilmemek mazeret sayılmaz." [8] Bu nedenle, ilgili Kanunların ilgili maddelerinin bilinmesi gerekir. Yazı içerisinde konu iki bölüm halinde gözden geçirilmiş ve değerlendirilmiştir.

- Illetişim adresi: Prof. Dr. İrfan Esenkaya, Sante Tıp Merkezi, Ortopedi ve Travmatoloji Bölümü. Fener Kalamış Cad. No: 32. Kalamış - Kadıköy, İstanbul Tel: 0532 - 32186 81, 0532 - 8632786 e-posta: iesenkaya@hotmail.com

- Geliş tarihi: 9 Ekim $2019 \quad$ Kabul tarihi: 6 Kasım 2019

* Tıp Hukuku Yüksek Lisansı, MA. 
Birinci bölümde; 4483 sayılı Memurlar ve Diğer Kamu Görevlilerinin Yargılanması Hakkındaki Kanuna göre, memurlar ve diğer kamu görevlilerinin görevleri sebebiyle işledikleri suçlardan dolayı yargılanabilmeleri için izin vermeye yetkili mercilerin (başvurulacak yerlerin, makamların) belirlenmesi ve izlenecek usul (yol) ile ilgili Kanun maddeleri değerlendirildi.[1] Daha sonra, T. C. Sağlık Bakanlığı İstanbul il Sağlık Müdürlüğü Disiplin Şube Müdürlüğünce yayımlanan iş akış süreçleri gözden geçirildi.[6]

İkinci bölümde; 657 Sayılı Devlet Memurları Kanunu ile 2547 sayılı Yükseköğretim Kanunu ve diğer yönetmeliklerin disiplin soruşturmaları ile ilgili maddeleri değerlendirildi. ${ }^{2-5]}$ SABIM ve CIMER kanallarıyla veya değişik kurumlar aracılığı ile il Sağlık Müdürlüğüne gelen ihbar ve şikâyetlerin değerlendirilmesinin nasıl yapıldığı gözden geçirildi. Daha sonra, konuyla ilgili olarak T. C. Sağlık Bakanlığı İstanbul ilı Sağlık Müdürlüğü Disiplin Şube Müdürlüğünce yayımlanan iş akış süreçleri gözden geçirildi. ${ }^{[6]}$

\section{SAYILI KANUN ${ }^{[1]}$}

\section{Sayılı Kanunun Amaç ve Kapsamı ${ }^{[1]}$}

Memurlar ve diğer kamu görevlilerinin görevleri sebebiyle işledikleri suçlardan dolayı yargılanabilmeleri için izin vermeye yetkili mercilerin (makamların) belirlenmesi ve izlenecek usul (yol), 4483 sayılı Memurlar ve Diğer Kamu Görevlilerinin Yargılanması Hakkındaki Kanunun birinci maddesiyle düzenlenmiştir. Madde 2'de, bu Kanunun; devletin ve diğer kamu tüzel kişilerinin genel idare esaslarına göre yürüttükleri kamu hizmetlerinin gerektirdiği asli ve sürekli görevleri ifa eden (yapan, yerine getiren) memurlar ve diğer kamu görevlilerinin görevleri sebebiyle işledikleri suçlar hakkında uygulandığı belirtilmiştir. Ayrıca, ağır cezayı gerektiren suçüstü durumların genel hükümlere tabi olduğu ifade edilmiştir.

\section{İzin Vermeye Yetkili Makamlar, Soruşturma İzni Yetkisi (4483 Sayılı Kanun, Madde 3) ${ }^{[1]}$}

Soruşturma izni yetkisi; ilçede kaymakam, ilde ve merkez ilçede vali tarafından verilir. Yetkili makamların saptanmasında, memur veya kamu görevlisinin suç tarihindeki görevi esas alınır. Ast memur ile üst memurun aynı fiile (olaya) iştirakı halinde izin, üst memurun bağlı olduğu makamdan istenir.

\section{Olayın Yetkili Makama illetilmesi, İşleme Konulmayacak ìhbar ve Şikayetler (4483 Sayıı Kanun, Madde 4) ${ }^{[1]}$}

Cumhuriyet başsavcıları, memurlar veya diğer kamu görevlilerinin bu Kanun kapsamına giren suçlarına ilişkin herhangi bir ihbar veya şikâyeti aldıklarında veya böyle bir durumu öğrendiklerinde, ivedilikle (acele olarak) toplanması gerekli ve kaybolma ihtimali bulunan delilleri toplamaktan başka hiçbir işlem yapmazlar. Hakkında ihbar veya şikâyette bulunulan memur veya diğer kamu görevlisinin ifadesine başvurmadan topladıkları evrakın bir örneğini ilgili makama göndererek soruşturma izni isterler.

Cumhuriyet başsavcıları dışındaki diğer makamlar ile memurlar ve kamu görevlileri de, bu Kanun kapsamına giren bir suç işlendiğini ihbar, şikâyet, bilgi, belge veya bulgulara dayanarak öğrendiklerinde durumu izin vermeye yetkili makama iletirler.

Bu Kanuna göre memurlar ve diğer kamu görevlileri hakkında yapılacak ihbar ve şikayetlerin somut ve özel niteliklerde olması, ihbar veya şikayetlerde kişi veya olay belirtilmesi, iddiaların ciddi bulgu ve belgelere dayanması, ihbar ve şikayet dilekçesinde dilekçe sahibinin doğru ad, soyad ve imzası ile iş veya ikametgah adresinin bulunması zorunludur (Değişik üçüncü fikra: 17/7/2004-5232/2 md.).

Yukarıdaki şartları (üçüncü fikradaki) taşımayan ihbar ve şikâyetler Cumhuriyet başsavcıları ve izin vermeye yetkili kurumlar tarafindan işleme konulmaz. Durum, ihbar ve şikâyette bulunana bildirilir. Ancak, iddiaların doğruluğunun şüphe yaratmayacak belgelerle ortaya konulmuş olması durumunda ad, soyad ve imza ile iş veya ikametgah adresinin doğruluğu şartı aranmaz. Başsavcılar ve yetkili makamlar ihbarcı veya şikâyetçinin kimlik bilgilerini gizli tutmak zorundadırlar (Değişik dördüncü fikra: 17/7/2004-5232/2 md.).

\section{Ön İnceleme (4483 Sayılı Kanun, Madde 5)[1]}

Ön incelemeye izin vermeye yetkili makam, bu Kanun kapsamına giren bir suç işlendiğini bizzat veya yukarıdaki maddede yazılı şekilde öğrendiğinde bir ön inceleme başlatır.

Cumhuriyet başsavcılıkları ile izin vermeye yetkili makamlar, ihbar ve şikâyetler konusunda daha önce sonuçlandırılmış bir ön inceleme olması halinde başvuruyu işleme koymazlar. Ancak ihbar veya şikayet eden kişi ya da kişilerin konuyla ilgili olarak daha önceki ön incelemenin neticesini etkileyecek yeni belge sunması halinde başvuruyu işleme koyabilirler (Ek fikra: 17/7/20045232/3 md.).

Ön inceleme, izin vermeye yetkili makam tarafindan bizzat yapılabileceği gibi, görevlendireceği bir veya birkaç denetim elemanı veya hakkında inceleme yapılanın üstü konumundaki memur veya kamu görevlilerinden biri veya birkaçı tarafından yaptırılabilir.

İnceleme yapacakların, izin vermeye yetkili makamın bulunduğu kamu kurum veya kuruluşunun içerisinden belirlenmesi esastır. İnceleme konusunun özelliğine 
göre bu makam, yapılacak incelemenin başka bir kurum veya kuruluşunun elemanlarıyla yaptırılmasını ilgili, kuruluştan isteyebilir.

Ön inceleme ile görevlendirilen kişiler birden fazla ise, içlerinden biri başkan olarak belirlenir.

\section{Ön İnceleme Yapanların Yetkisi ve Rapor (4483 Sayılı Kanun, Madde 6) ${ }^{[1]}$}

Ön inceleme ile görevlendirilen kişi veya kişiler, bakanlık müfettişi ile kendilerini görevlendiren makamın bütün yetkilerine sahip olup, bu Kanunda hüküm bulunmayan konularda Ceza Muhakemeleri Usulü Kanununa göre işlem yapabilirler.

Hakkında inceleme yapılan memur veya diğer kamu görevlisinin ifadelerini de almak suretiyle yetkileri dâhilinde bulunan gerekli bilgi ve belgeyi toplayıp, görüşlerini içeren bir rapor düzenleyerek durumu izin vermeye yetkili makama sunarlar.

Ön inceleme birden çok kişi tarafından yapılmışsa, farklı görüşler raporda gerekçeleriyle ayrı ayrı belirtilir.

Yetkili makam bu rapor üzerine soruşturma izni verilmesine veya verilmemesine karar verir. Bu kararda gerekçe gösterilmesi zorunludur.

\section{Ön İnceleme Süresi ve Uzatma Süresi (4483 Sayılı Kanun, Madde 7) ${ }^{1]}$}

Yetkili makam, soruşturma izni konusundaki kararını, suçun 5'inci maddenin birinci fikrasına göre öğrenilmesinden itibaren ön inceleme dâhil en geç otuz gün içinde verir. Bu süre, zorunlu hallerde on beş günü geçmemek üzere bir defa uzatılabilir.

\section{İtirazlar ve İtiraz Süresi (4483 Sayılı Kanun, Madde 9)[1]}

Soruşturma izni verilmesine ilişkin karara karşı, hakkında inceleme yapılan memur veya diğer kamu görevlisi itiraz yoluna gidebilir. Aynı şekilde, soruşturma izni verilmemesine ilişkin karara karşı da Cumhuriyet başsavcılığı veya şikâyetçi itiraz edebilir. İtiraz süresi, yetkili makamın kararının tebliğinden (bildirilmesinden) itibaren on gündür.

İtiraza, il veya ilçedeki görevli memurlar ve diğer kamu görevlileri için, yetkili makamın yargı çevresinde bulunduğu Bölge İdare Mahkemesi bakar. İtirazlar öncelikle incelenir ve en geç üç ay içerisinde karara bağlanır. Verilen kararlar kesindir.

\section{T. C. SAĞLIK BAKANLIĞI ISTANBUL IL SAĞLIK MÜDÜRLÜĞÜ DisiPLIN ŞUBE MÜDÜRLÜĞÜNCE YAYIMLANAN iş AKIŞ SÜREÇLERi[6]}

İstanbul için ele alındığında; 4483 sayılı Devlet Memurlarının Yargılanması Usulü Hakkında Kanun kapsamında işlenen suçlar sebebiyle gerek re'sen (kendi başına, kendiliğinden) idarece başlatılan, gerekse savcılık talebiyle yapılmakta olan ön incelemeler, sürenin kısıtlı olması, sonuçlarının ağır olabilmesi ile daha teknik ve ayrıntılı bir çalışma gerektirmesi sebebiyle T.C. Sağlık Bakanlığı İstanbul il Sağlık Müdürlüğü bünyesindeki Disiplin Şube Müdürlüğünce takip edilmektedir. Konuyla ilgili iş akış süreçleri belirlenmiştir. ${ }^{[6]}$ Aşağıda bu süreçler bildirilmiştir.

4483 sayılı Memurlar ve Diğer Kamu Görevlilerinin Yargılanması Hakkındaki Kanuna göre ön inceleme yapılması talebiyle gelen yazıların değerlendirilmesi ${ }^{[1,6]}$

- Savcilıktan gelen 4483 sayılı Kanuna göre işlem yapılması talepli yazı değerlendirilir.

- Şikâyet konusu ile ilgili bilgi ve belgelerin temin edilmesi için ilgili kurumlardan bilgi istenir.

- Gelen bilgi ve belgeler değerlendirilir.

- Ön inceleme yapılmasına engel bir durum var ise, savcılığa ön inceleme başlatılmadığı bildirilir.

- Hakkında soruşturma izni istenen görevlinin üniversite personeli olması durumunda, dosya ilgili rektörlüğe gönderilir ve Savcılığa bu yönde bilgi verilir.

- Ön inceleme başlatılmasını gerektirecek bir durum var ise, Valilik oluru ile muhakkik (ön incelemeci) görevlendirmesi işlemine geçilir.

\section{3 sayılı Kanuna göre Valilik Oluru ile muhakkik (ön incelemeci) görevlendirilmesi ${ }^{[1,6]}$}

- Ön inceleme yapması için uygun bir ön incelemeci araştırması yapılır. Şikâyet konusuna uygun branşta ve idari kadroda bir ön incelemecinin tayin edilmesi (atanması, belirlenmesi) gerekir.

- Değerlendirmeler yapılarak uygun bir ön incelemeci atanır. Uygun unvan, kadro ve branş olması dışında üzerinde halen incelemesini yaptığı bir görevlendirmenin bulunup bulunmadığı, ön inceleme eğitimi alıp almadığı, daha önce verilen görevlendirmeleri usulüne uygun yapıp yapmadığı gibi özellikler göz önünde bulundurulur.

- Valilik Oluru hazırlanarak Valilik Makamına sunulur.

- Valilik Oluru imzalandıktan sonra il Sağlık Müdürlüğü Disiplin Şube Müdürlüğüne ulaştıktan sonra ekleriyle birlikte ön incelemecinin kurumuna gönderilir.

\section{Ön incelemecinin raporunu hazırlama süresince yapılan işlemler ${ }^{[6]}$}

- Ön inceleme için süre, olayın öğrenildiği tarih olan Valilik Olur tarihinden itibaren başlar. Ön 
incelemenin 30 gün içinde tamamlanması gerekmektedir. Bu süreye ek olarak en fazla 15 gün verilebilmektedir. Yoğun olan illerde bu ek süre talep edilmeden, Valilik Olurunda baştan verilebilmektedir.

- Valilik Olur tarihinden itibaren 30 gün ve 40 gün dolduğunda ön incelemeciye hatırlatma yazıları, 45 gün dolduğunda yasal sürenin dolduğuna dair hatırlatma yazıları yazılır.

- Ön inceleme raporu teslim edilene kadar il Sağlık Müdürlüğü Disiplin Şube Müdürlüğü tarafindan dosyanın takibine devam edilir. Rapor teslim edildiğinde de kriterlere uygunluğu değerlendirilir.

\section{Ön incelemeci tarafindan düzenlenen ön inceleme raporuna dayanarak yapılan işlemler ${ }^{[6]}$}

- Ön incelemeci tarafindan hazırlanarak teslim edilen ön inceleme raporunda tespit edilen bir eksiklik saptanırsa rapor iade edilir ve belirtilen eksiklikler giderilerek ön inceleme raporunun yeniden düzenlenmesi istenir.

- Formata uygun olarak hazırlanan ön inceleme raporuna, 4483 sayılı Kanuna göre karar yazılır ve imza için Valilik Makamına sunulur.

\section{Valilikçe ön inceleme raporuna istinaden 4483 sayılı Kanuna göre alınan karar ile ilgili işlemler ${ }^{[1,6]}$}

- 4483 sayılı Kanuna göre alınan karar Valilik makamından geldiğinde Savcılığa, müştekiye (şikâyette bulunana) ve hakkında karar alınan görevliye tebliğ (bildirmek, haber vermek için) için yazışmalar yapilır.

- Tebligatlar yapıldıktan sonra itiraz süreleri beklenir.

- İtiraz olması durumunda karar ile ilgili dosya Bölge İdare Mahkemesine sunulur.

- İtiraz olmazsa kesinleşen karar ile ilgili Savcılığa bilgi verilerek soruşturmanın seyri takip edilir.

4483 sayılı Kanuna göre alınan kararın kesinleşmesini takiben yapılan savcılık/mahkeme yazışmaları ${ }^{[1,6]}$

- Alınan kararlara 10 gün içinde itiraz edilmediği takdirde ilgili karar kesinleşmiş olur.

- İtiraz olduğu durumlarda ise, Bölge İdare Mahkemesince verilen karara itiraz hakkı bulunmadığı için, 4483 sayılı Kanuna göre verilen karar kesinleşmiş olur.

- Soruşturma izni verilmemesi olarak kesinleşen karara dayanarak Savcılıktan bilgi istenir. Savcılık kovuşturmaya yer olmadığına dair karar vererek, ilgili kararı ön incelemeyi başlatan kuruma (burada iı
Sağlık Müdürlüğüne) gönderir. Savcılık kararı, ilgililerin dosyasına konulmak üzere kurumlarına gönderilir.

- Soruşturma izni verilmesi olarak kesinleşen karara dayanarak, Savcılık soruşturma izni verilenler hakkında iddianame düzenler.

- İddianame ilgili Mahkemede kabul edilirse hakkında dava açılanların safahatı (süreci) başlamış olur.

Soruşturma: Suçun işlenmesinden başlayarak yargı verilinceye dek, kolluk, savcı, yargıç yönünden yapılan inceleme, araştırma ve kanıtların toplanması işleminin tümü. ${ }^{[9]}$

Yargı: Hukuk kurallarının bağımsız ve tarafsız mahkemelerce belli bir olaya uygulanmasıdır. ${ }^{[9]}$

Kovuşturma: Iddianamenin savcılık aşamasından sonra mahkemenin kabul etmesiyle savcılıktan sonra karar verilmesine kadarki süreç. ${ }^{[9]}$

\section{SAYILI DEVLET MEMURLARI KANUNU[2]}

Disiplin suçu, iş hayatında bir kimsenin disiplin yönetmeliğine aykırı davranışıdır. Disiplin cezası ise, disiplin suçlarından birisini işleyen kimseye davranışının ağırlık derecesine göre verilen cezadır. ${ }^{[7]}$

657 sayılı Devlet Memurları Kanunu'na göre, disiplin rejiminin genel amacı, kamu hizmetlerinin gereği gibi yürütülmesini sağlamaktır. Cezaya konu edilen eylem ve durumlar incelendiğinde, kurulan sistemin iki amaca yönelik olduğu görülmektedir; ${ }^{[2,7]}$

1. Kamu kurumunda iç çalışma düzenini, memurun ihmal (kayıtsızlık gösterme, düzensiz davranma), kusur ve kasıt yoluyla yaptığı eylemleri cezalandırarak korumak,

2. Görev ve yetkinin özel çıkar amacıyla kullanılmasını önlemektir.

Disiplin soruşturmasında uygulanması gereken temel mevzuat 657 sayılı Devlet Memurları Kanununun disiplinle ilişkili hükümleridir. ${ }^{[2]}$ Ayrıca farklı kurumların kendi Disiplin Yönetmelikleri ve iş akış süreçleri vardır. ${ }^{[4-7]}$

657 sayılı Devlet Memurları Kanununun Disiplinle ilgili bölüm 7'deki ilgili 124'üncü maddeye göre; “Kamu hizmetlerinin gereği gibi yürütülmesini sağlamak amacı ile Kanunların, Cumhurbaşkanlığı kararnamelerinin ve yönetmeliklerin Devlet memuru olarak emrettiği ödevleri yurt içinde veya dışında yerine getirmeyenlere, uyulması zorunlu kıldığı hususları yapmayanlara, yasakladığı işleri yapanlara durumun niteliğine ve ağırlık derecesine göre 125 'inci maddede sıralanan disiplin cezalarından biri verilir." $125^{\prime}$ inci maddede, devlet memurlarına verilen disiplin cezaları ile her bir disiplin cezası gerektiren durumlar ayrıntılarıyla belirtilmiştir. ${ }^{[2]}$ 


\section{SAYILI YÜKSEKÖĞRETIM KANUNU[3]}

2547 sayılı Yükseköğretim Kanununda madde 53/A'da disiplin soruşturmasında uyulacak esaslar bildirilmiştir. Buna göre; (a) Disiplin cezası verilmesini gerektiren bir fiilin işlendiğini öğrenen disiplin amiri yazılı olarak disiplin soruşturması başlatır. (b) Bilimsel araştırma ve yayın etiğine ilişkin disiplin cezası verilmesini gerektiren fiiller açısından soruşturma başlatılmadan önce bilimsel araştırma ve yayın etiği kurullarınca inceleme yapılması zorunludur. (c) Disiplin amiri soruşturmayı kendisi yapabileceği gibi soruşturmayı yapmak üzere birim içerisinden soruşturmacı veya komisyon görevlendirebilir. Ancak zorunlu hallerde rektörlük aracılığıyla diğer birimlerden soruşturmacı talep edilebilir. (d) Soruşturmacının görev ve unvanı, soruşturulanın görev ve unvanının üstünde veya onunla aynı düzeyde olmalıdır. (e) Fiilin ast ile üst tarafından birlikte işlenmesi hâlinde soruşturma usulü ve disiplin cezası verme yetkisi üste göre belirlenir. ( $f$ ) Soruşturulanın disiplin cezası verilmesini gerektiren fiili işlediği ve disiplin soruşturmasının başlatıldığı tarihteki görev veya unvanının farklı olması hâlinde disiplin soruşturması, üst görev veya unvanı esas alınarak yürütülür. Disiplin amirinin belirlenmesi ve uygulanacak diğer disiplin hükümleri, görev yapılan kurumun tabi olduğu mevzuata göre belirlenir. (g) Soruşturmacı, disiplin soruşturmasıyla ilgili bilgi ve belgeleri toplama, ifade alma, tanık dinleme, bilirkişiye başvurma, keşif yapma, inceleme yapma ve ilgili makamlarla yazışma yetkisine sahiptir. (h) Soruşturmacının, görevlendirme kapsamında talep ettiği bilgi ve belgeler gecikmeksizin kendisine verilir. ( ) Soruşturmacı, görevlendirildiği konuda soruşturma yürütür; soruşturma sırasında disiplin soruşturmasına konu olabilecek başka fiillerin ortaya çıkması durumunda bunları gecikmeksizin disiplin amirine bildirir. (j) Soruşturma işlemleri bir tutanakla tespit olunur. (k) Soruşturmanın gizliliği esastır. (I) Soruşturma, görevlendirme yazısının tebliğ tarihinden itibaren iki ay içinde tamamlanır. Soruşturma bu süre içinde tamamlanamaz ise soruşturmacı gerekçeli olarak ek süre talep edebilir, disiplin amiri gerekçeyi değerlendirerek ve zaman aşımı sürelerini dikkate alarak karar verir. (m) Fiili işleyenin emeklilik veya başka nedenlerle görevinin sona ermesi, hakkında soruşturma açılmasına ve soruşturmanın devamına engel olmaz. Bu durumda soruşturma sonunda verilen disiplin cezası, özlük dosyasında saklanır. Aylıktan veya ücretten kesme ve kademe ilerlemesinin durdurulması veya birden fazla ücretten kesme cezaları ilgilinin kamu görevine dönmesi ya da bir vakıf yükseköğretim kurumunda göreve başlaması halinde uygulanır. (n) Bir fiilden dolayı ilgili hakkında ceza soruşturması veya kovuşturması yapılıyor olması, aynı fiilden dolayı disiplin soruşturması yapılmasına, ceza verilmesine ve bu cezanın yerine getirilmesine engel değildir. Gerektiğinde ceza kovuşturması bekletici mesele yapılabilir. Bu durumda disiplin soruşturmasına ilişkin zaman aşımı süreleri durur. (o) Bir fiilin diğer Kanunlar uyarınca idari yaptırıma bağlanmış olması, aynı fiile bu Kanun kapsamında disiplin cezası verilmesine engel teşkil etmez.

Savunma hakkı kapsamında gözetilecek hususlar şunlardır: (a) Soruşturulana, iddialar hakkında savunma imkânı tanınmadan disiplin cezası verilemez. Soruşturmayı yapanın yedi günden az olmamak üzere verdiği süre içinde veya belirtilen tarihte geçerli bir mazereti olmaksızın savunmasını yapmayan, savunma hakkından vazgeçmiş sayılır. (b) Savunmaya davet yazısında hakkında disiplin soruşturması açılan fiilin neden ibaret bulunduğu, savunmasını belirtilen sürede yapmadığı takdirde savunmasından vazgeçmiş sayılacağı bildirilir. (c) Disiplin cezası vermeye yetkili makamlar gerek görürse, isnat edilen fiil ve soruşturma raporunda önerilen disiplin cezasını da belirtmek suretiyle, bu maddedeki esaslar çerçevesinde (a) ve (b) bentlerindeki usule göre tekrar savunma isteyebilir. Hakkında üniversite ögrretim mesleğinden çıkarma ve kamu görevinden çıkarma cezası istenenler soruşturma evrağını inceleme, tanık dinletme, disiplin kurulunda sözlü veya yazılı olarak kendisi veya vekili vasıtasıyla savunma yapma hakkına sahiptir.

\section{T. C. SAĞLIK BAKANLIĞI ISTANBUL İL SAĞLIK MÜDÜRLÜĞÜ DISIPLIN ŞUBE MÜDÜRLÜĞÜNCE YAYIMLANAN iş AKIŞ SÜREÇLERi[[]}

SABIM ve CIMER kanallarıyla veya değişik kurumlar aracılığı ile il Sağlık Müdürlüğüne gelen ihbar ve şikâyetlerin kayıt edilip mevzuata uygunlukları değerlendirildikten sonra da disiplin soruşturması başlatılabilmektedir. ${ }^{[6]}$

\section{Gelen ihbar ve şikâyete dayanarak inceleme ve soruşturmanın başlatılması [6]}

- il Sağlık Müdürlüğüne gelen şikayet veya ihbar başvuruları kriterlere uygunluk ve kapsam yönünden değerlendirilir. Eğer inceleme/soruşturma başlatılmasına karar verilirse uygun bir muhakkik (ön incelemeci) belirlenir. Disiplin Şube Müdürlüğü tarafindan il Sağlık Müdürlük Makamına sunulur.

- Şikâyet konusuna ve şikayet edilen bölgeye uygun ön incelemeci atanması için araştırma yapılır. Uygun unvan, kadro ve branş olması dışında üzerinde halen incelemesini yaptığı bir görevlendirmenin bulunup bulunmadığı, ön incelemeci eğitimi alıp almadığı, daha önce verilen görevlendirmeleri usulüne uygun yapıp yapmadığı gibi özellikler göz önünde bulundurulur. 
- Muhakkik (ön incelemeci) tayin edildikten sonra Müdürlük Oluru hazırlanarak Müdürlük Makamına sunulur.

- Müdürlük Oluru imzalanarak ekleriyle birlikte en kısa sürede ön incelemeciye teslim edilmesi için ön incelemecinin kurumuna sevk edilir.

\section{Muhakkikin inceleme/disiplin soruşturma raporunu hazırlama süreci ${ }^{[6]}$}

- Inceleme/disiplin soruşturmalarında, ön incelemecinin görevlendirmeyi tebliğ ettiği tarihten itibaren 30 gün içerisinde incelemeyi tamamlaması istenilmektedir. Dosyanın içeriğine göre ön incelemeci ek süre isteyebilir. Raporun tamamlanması, dosyadaki zaman aşımı süresine göre iki yıla kadar çıkabilmektedir.

- Ön incelemecinin ek süre talep ettiği durumlarda dosyada zaman aşımı olup olmadığı değerlendirilir. Duruma göre ek süre verilebilir veya ek süre verilmeyeceğine dair ön incelemeciye bilgi verilir.

- Ön incelemeci gerekçe göstererek görevlendirmeden affını isteyebilir. Bu talep Müdürlük Makamı Oluru ile olumlu ya da olumsuz olarak değerlendirilip kendisine bildirilir.

- İnceleme/disiplin soruşturma raporu Müdürlüğg teslim edilene kadar dosya takip edilir.

Ön incelemeci tarafindan teslim edilen inceleme/disiplin soruşturma raporuna dayanarak yapılan işlemler ${ }^{[6]}$

- Teslim edilen rapor mevzuata uygunluk yönünden değerlendirilir.

- Usulüne uygun olarak hazırlanan inceleme/disiplin soruşturma raporu, belirtilen kanaate istinaden, hakkında inceleme yapılanın disiplin amirine gönderilir.

- Disiplin soruşturma raporunda "kademe ilerlemesinin durdurulması" cezası teklifi bulunması halinde rapor ve ekleri il Disiplin kuruluna sunulur.

- Disiplin soruşturma raporunda "devlet memurluğundan çıkarma" cezası teklifi bulunması halinde rapor ve ekleri Yüksek Disiplin kuruluna sunulur.

\section{Disiplin soruşturma raporuna istinaden verilen cezaya yapilan itirazlar ${ }^{[2,6]}$}

- 657 sayılı Devlet Memurları Kanununun 125’inci maddesi gereğince verilen cezalara itiraz süresi 7 gündür. Bütün disiplin cezalarına karşı idari yargı yolu açıktır.

- İtiraz makamları, itiraz dilekçesi ile ceza ve eklerinin kendilerine intikalinden itibaren 30 gün içerisinde kararlarını vermek zorundadırlar.

\section{Disiplin soruşturma raporunun düzenlenmesi ${ }^{[7]}$}

Soruşturma tamamlandığında bu konuda bir rapor düzenlenmesi zorunludur. Soruşturma raporu:

- Soruşturma onayının tarih ve sayısı,

- Soruşturmaya başlama tarihi,

- Disiplin amirinin isnat edilen fiil ve hali öğrenme tarihi,

- Muhbir veya müştekinin kimlik bilgileri,

- Hakkında soruşturma yapılanın kimliği ve resmi sıfatı,

- İddia konusu olay,

- Fiil veya halin gerçekleştiği tarih ve yer,

- Soruş̧turma maddeleri,

- Savunma,

- Leh ve aleyhe olan deliller,

- Delillerin tartışılması,

- Sonuç

bölümlerinden oluşur.

Isnat: Bir düşünceyi, bir konuyu bir kişi veya nedene dayandırma, yükleme, atfetme. ${ }^{[9]}$

\section{YÜKSEKÖĞRETIM KURUMLARI, YÖNETICi, ÖĞRETIM ELEMANI VE MEMURLARI DISIPLIN YÖNETMELiĞi[9]}

Yükseköğretim Kurumları, Yönetici, Öğretim Elemanı ve Memurları Disiplin Yönetmeliği'nin 17'inci maddesinde; disiplin suçunu soruşturmaya yetkili amirin, sıralı disiplin amirleri olduğu belirtilmiştir. Aynı maddeye göre; "Öğretim elemanlarından soruşturmacı tayin edilmesi halinde, bu soruşturmacıların sanığın akademik unvanına veya daha üst akademik unvana sahip olmaları şarttır. Yöneticiler hakkındaki soruşturmalarda unvan eşitliği veya üstlüğü aranır." denmektedir. Madde 20'de, aynı olaydan dolayı yönetici, öğretim elemanı, memur veya diğer görevliler hakkında ceza muhakemesinde kovuşturmaya başlanmış olması, disiplin kovuşturmasını geciktirmediği belirtilmiştir. Madde 22'de soruşturma süresine değinilmiştir; "Soruşturmanın soruşturmacı tayini suretiyle yapılması halinde, soruşturma kararı gecikilmeksizin soruşturmacıya bildirilir. Soruşturmacı, soruşturmayı kararın kendisine tebliğinden itibaren iki ay içerisinde bitirir. Bu süre içerisinde soruşturma bitirilmiyor ise soruşturmacı, gerekçeli olarak ek süre talebinde bulunur. Disiplin amiri, ek süre vermesi halinde, durumu bir üst disiplin amirine bilgi olarak sunar." Madde 23'te soruşturmanın yapılış şeklinden bahsedilmiştir; "Soruşturmacı tanık dinler, keşif 
yapabilir ve bilirkişiye başvurabilir. Her soruşturma işlemi bir tutanakla tespit olunur. Tutanakta, işlemin nerede ve ne zaman yapıldığı, işlemin mahiyeti, kimlerin katıldığı, ifade alınmış ise, soruları ve cevapları belirtecek şekilde düzenlenir ve soruşturmacı, kâtip ile ifade sahibi veya keşif sırasında hazır bulundurulanlar veya belge sorumlularınca imzalanır. Sorulacak sorular dikkatle tespit olunur. Şahide yemin ettirilmesi hususu belirtilir ve yaptırılacak yeni şekli de yazılır." Aynı maddeye göre; "Yükseköğretim Kurumlarının bütün personeli veya diğer kamu veya özel kuruluş yetkilileri disiplin soruşturmacılarının istedikleri her türlü bilgi, dosya ve başka belgeleri hiçbir gecikmeye mahal bırakmaksızın vermeye ve istenecek yardımları yerine getirmeye mecburdurlar." [4]

\section{TÜRK TABIPLERI BiRLIĞi (TTB) DisiPLIN YÖNETMELiĞi[j]}

TTB Disiplin Yönetmeliğinin 13'üncü maddesinde ilk inceleme ve soruşturmacı atanmasının nasıl yapılacağı belirtilmiştir. ${ }^{[5,10]}$ Madde 13'e göre; [5,10]

- Oda yönetim kurulu, bildirim veya yakınmanın yapılmasından sonra bir ay içinde konuyu inceler.

- Yönetim kurulu bildirim veya yakınmayı değersiz görürse, soruşturma açılmasına yer olmadığına dair kararını şikâyet eden tarafa bildirir.

- Bildirim veya yakınma soruşturmaya değer görüldüğünde ise, yönetim kurulu; 1 ) ilgiliye yakınma veya bildirim konusunu yazılı olarak bildirerek tebliğinden itibaren en geç 15 gün içinde savunmasını ve varsa kanıtlarını bildirmesini ister. Ya da; 2) Yönetim kurulu, bildirim veya yakınmayı inceleyerek gerekli gördüğü durumlarda oda üyelerinden birini veya birkaçını soruşturmacı olarak atar. Soruşturmacı yönetim kurulu kararı ile atanır. Soruşturmacı, bu kararın örneğini veya tarih ve sayısını, hakkında suçlamada bulunulan kişiye bildirir. Soruşturmacı olarak atanan hekim haklı sebeplerle görevi kabul etmeyebilir. Yönetim kurulu tarafından tabip odası sınırları içinden soruşturmacı atanması uygun görülmediği takdirde soruşturmacı belirlenmesi Merkez Konseyi'nden istenebilir.

TTB Disiplin Yönetmeliğinin 14'üncü maddesinde soruşturmanın yapılış biçimi belirtilmiştir. Madde 14'e göre; ${ }^{[5,10]}$

- Soruşturmacı, hakkında soruşturma açılan kişiye suçlamayı açık ve anlaşılır bir biçimde yazılı ve "gizli" ibareli olarak tebliğ ederek, tebliğden itibaren 15 gün içinde savunma yapılmasını ister. Bu süre içinde savunmasını vermeyen kişi, savunma hakkından vazgeçmiş sayılır. Gerekli görülen durumlarda suçlanan kişinin sözlü savunması da istenebilir.

- Soruşturmacı, kişinin leh ve aleyhindeki bütün kanıtları toplamakla yükümlüdür. Bu nedenle olayla ilgili tüm kişilerin ya da kuruluş yöneticilerinin bilgilerine başvurabilir, resmi makamlardan belge isteyebilir, tanıkların sözlü anlatımlarına da başvurabilir. Soruş̧urmacı, ilgili birimlerle yazışmasını "gizli" ibareli olarak yapar.

- Soruşturmacı her türlü ifade ve benzeri tutanağı kendisi yazabileceği gibi, tabip odası yönetim kurulunca görevlendirilecek bir yeminli sekretere de yazdırabilir.

- Soruşturmacı, suçlanan kişinin beyanının alınmasından veya bunun için öngörülen sürenin dolmasından ve delillerin toplanmasından itibaren 20 gün içinde soruşturma dosyasını tamamlayarak fezlekesi ile birlikte yönetim kuruluna sunar.

- Gerekli ifadeleri ve belgeleri toparlayan soruşturmacı, bir fezleke düzenler. Fezlekede suçlama konusu olay ile lehte ve aleyhteki tüm belge ve ifadeler tartışılır. Soruşturmacı fezlekenin sonuç bölümüne, kişinin kusurlu olup olmadığı ve verilmesini uygun gördüğü ceza konusunda kendi kişisel yargısını da ekler. Ancak bu yargı yönetim kurulu ve onur kurulu açısından bağlayıcı değildir.

- Yönetim kurulu, soruşturma raporunu eksik görürse, eksikliği en çok iki ay içinde tamamlatır.

- Soruş̧turmacının ilk inceleme sırasında yapacağı tüm harcamalar belge ile kanıtlanmak koşuluyla tabip odası bütçesinden ödenir, gerektiğinde avans da verilebilir. Soruşturmacıya mesaisi ile orantılı olarak oda bölgesinde geçerli asgari muayene ücretinin bir ila beş katı tutarında; soruşturma öncesinde veya soruşturma sürecinde görevlendirilen bilirkişilere, verdikleri emek ve raporun kapsamına göre, asgari muayene ücretinin bir ila üç katı tutarında bir ücret, yönetim kurulunca takdir edilebilir.

- Soruşturmanın en kısa süre içinde tamamlanması için yönetim kurulu her türlü önlemi almak, gerektiğinde soruşturmacıyı görevden alarak yeni bir soruşturmacı ile soruşturmayı yürütmek zorundadır.

Fezleke: Bir tahkikat veya muhakeme tutanağının özeti demektir. Bunda tafsilata (ayrıntıya) girişilmeden işin ana hatları gösterilir. Bir teftiş raporunun kısaltılması halinde iktisab ettiği şekle de denir. ${ }^{[9]}$

iktisab: Kazanma ile ilgili; edinme ile ilgili.[9] 


\section{Yapılan ön incelemelere istinaden alınan kararların istanbul Bölge Idare Mahkemesi tarafindan bozulabilme nedenleri}

Yapılan ön incelemelere dayanarak alınan kararların İstanbul Bölge İdare Mahkemesi tarafindan bozulma nedenlerinin bir kısmının bazı usul (yöntem) hatalarından kaynaklandığı bildirilmiştir. Bu nedenle ön inceleme yaparken belirtilen hususların dikkate alınmasını ilgili makamlarca önerilmektedir:

1- Müşterek olarak yapılan incelemelerde ifadeler başkan dâhil ön incelemeciler tarafindan birlikte alınmalıdır. İfade tutanakları ve düzenlenecek raporlar birlikte imzalanmalı ve sayfalar paraflanmalıdır.

2- Valilik Onayında belirtildiğinde veya gerekli görüldüğünde alınan bilirkişi görüşleri "Bilirkişi Raporu” başlı̆̆ında hazırlanmalıdır ve sadece bilirkişi tarafından imzalanmalıdır.

3 - Müştekinin (şikâyette bulunanın) dilekçesinde belirtilen tüm hususların dikkate alınarak ön inceleme yapılmalıdır.

4- Müştekinin ifadesinin alınması sonrası ve ifadelerde "hakkında ön inceleme yapılan ile tanık olarak alınan ifadelerin" ayrımı iyi yapılmalıdır. Ayrım, hem ifade tutanağı başlığında hem de ön inceleme raporunda belirtilmelidir.

5- Ön inceleme ve inceleme raporlarının sayfaları paraflanmalı, imzalanmalı ve ifade tutanakları eksiksiz imzalanmalıdır.

\section{KAYNAKLAR}

1. Memurlar ve Diğer Kamu Görevlilerinin Yargılanması Hakkında Kanun. Kanun Numarası: 4483, Kabul Tarihi: 2/12/1999. Yayımlandığı Resmî Gazete; Tarih: 4/12/1999, Sayı: 23896. Yayımlandığı Düstur; Tertip: 5, Cilt: 39. https:// mevzuat.gov.tr/MevzuatMetin/1.5.4483.pdf Alınma tarihi: 01.09.2019.

2. Devlet Memurları Kanunu. Kanun Numarası: 657, Kabul Tarihi: 14/7/1965. Yayımlandığı Resmî Gazete: Tarih: 23/7/1965, Sayı: 12056. Yayımlandığı Düstur; Tertip: 5, Cilt : 4, Sayfa: 3044. https://www.mevzuat.gov.tr/ MevzuatMetin/1.5.657.pdf Alınma tarihi: 01.09.2019.

3. Yükseköğretim Kanunu. Kanun Numarası: 2547, Kabul Tarihi: 4/11/1981. Yayımlandığı Resmî Gazete; Tarih: 6/11/1981, Sayı: 17506. Yayımlandığı Düstur; Tertip: 5, Cilt: 21, Sayfa:3. https://mevzuat.gov.tr/MevzuatMetin/1.5.2547.pdf Alınma tarihi: 01.09.2019

4. Yükseköğretim Kurumları Yönetici, Öğretim Elemanı ve Memurları Disiplin Yönetmeliği. https://dosya.marmara. edu.tr/ydyo/Formlar\%20ve\%20Raporlar/Y_KSEK_RET_M_ KURUMLARI_D_S_PL_N_Y_NETMEL_.pdf Alınma tarihi: 01.09.2019.

5. Türk Tabipleri Birliği Disiplin Yönetmeliği. Resmî Gazete: Tarih 28.04.2004, Sayı 25446. http://www.ttb.org.tr/mevzuat/ index.php? option $=$ com_content\&view $=$ article\&id $=125$ : $t$ ktablerbldl-yetmel\&catid=2:ymelik\&ltemid=33 Alınma tarihi: 01.09 .2019

6. T.C. Sağlık Bakanlığı, İstanbul îl Sağlık Müdürlüğü, Disiplin Şube Müdürlüğü, İ̧̧ Akış Süreçleri. http://www.istanbulsaglik. gov.tr/w/anasayfalinkler/belge/disiplin_sb.pdf Alınma tarihi: 01.09.2019.

7. T.C. Adalet Bakanlığı, Aday Memur Hazırlayıcı Eğitimi, Disiplin Soruşturması Ders Notu. https://edb.adalet.gov. tr/e-book/9-DisipLiNSORUŞTURMASI.PDF Alınma tarihi: 01.09.2019.

8. Türk Ceza Kanunu. Kanun Numarası: 5237, Kabul Tarihi: 26/9/2004. Yayımlandığı Resmî Gazete; Tarih: 12/10/2004, Sayı: 25611. Yayımlandığı Düstur; Tertip: 5, Cilt: 43. https:// mevzuat.gov.tr/mevzuatmetin/1.5.5237.pdf Alınma tarihi: 01.09.2019

9. T.C. Adalet Bakanlığı Hukuk Sözlüğü. https://sozluk.adalet. gov.tr/ Alınma tarihi: 01.09.2019

10. Hakeri H. Tıp Hukuku, 10. Baskı. Ankara: Seçkin Yayıncılık; 2015. ss.63-72. 